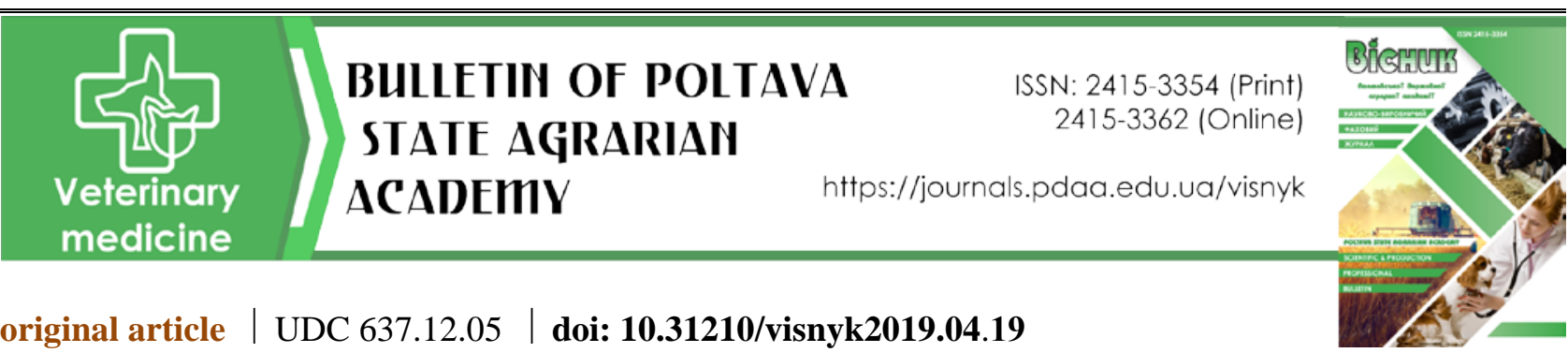

THE INFLUENCE OF TOXIC ELEMENTS ON ORGANOLEPTIC MILK INDICATORS

N. S. Shcherbakova, ORCID ID: 0000-0002-3573-7673,E-mail: peredera@ukr.net,

Yu. Yu. Maksymova,

E-mail:maksimovau987@mail.com,

Poltava State Agrarian Academy, 1/3, Skovorody str., Poltava, 36003, Ukraine

Heavy metals, which are toxic to humans and animals, are one of the most dangerous forms of food and the environment contamination. These substances penetrate into the human body mainly through food. For this reason, it is important to identify sources of accumulation and pollution and trace the pathways of these metals to farm products. The prevention of heavy metals' hazardous impact on human health has to be based on measures covering the entire migration link, from reducing metal accumulation in the natural environment to controlling their content in food. Farm animals are the leading link in the soil-plant-animal-food system, as they receive various organic substances and chemical elements, including heavy metals with feed and water. Milk is the most "susceptible" to heavy metals. The most toxic elements are lead, mercury, cadmium, zinc and arsenic. The research was conducted in 2019 at the Regional State Laboratory of the State Food Consumer Service in Poltava region. Altogether 12 samples of cow's whole milk were examined - one sample per batch. While examining the attention was paid to organoleptic indicators: color, taste, smell, and consistency. At conducting chemical-analytical studies of milk the mass concentration of micro- and macroelements was determined using appropriate test procedures and modern devices. As a result, it was found that the content of mercury $(\mathrm{Hd})$ in the tested samples was in accordance with the standard. The content of cadmium (Cd) in sample № 2 was $0.056 \mathrm{mg} / \mathrm{kg}$, in sample № $3-0.042 \mathrm{mg} / \mathrm{kg}$, in sample № $9-0.047$, and in sample № $10-0.059$ at the maximum permissible level of $0.03 \mathrm{mg} / \mathrm{kg}$, which was $86.6 \%, 40 \%$, $56 \%$ and $96 \%$ respectively higher than the standard. Zinc ( $\mathrm{Zn})$ values in the test samples were within the standard range. Lead content (Pb) in sample № 2 was $0.233 \mathrm{mg} / \mathrm{kg}$, which was $133 \%$ higher than the standard. Lead content $(\mathrm{Pb})$ in sample № 3 was $0.285 \mathrm{mg} / \mathrm{kg}$, which was $185 \%$ higher than the maximum permissible levels. In sample № 9, lead content was 0.249 and in sample № 10 it was 0.265 , which was $149 \%$ and $165 \%$ respectively higher than the standard. The concentration of arsenic (As) in the test samples was within the normal range. In terms of organoleptic characteristics, all the tested samples met the state requirements of DSTU 3662:2018 "Raw cow milk. Specifications".

Key words: heavy metals, toxic elements, organoleptic parameters, milk contamination, chemicalanalytical studies.

\title{
ВПЛИВ ТОКСИЧНИХ ЕЛЕМЕНТІВ НА ОРГАНОЛЕПТИЧНІ ПОКАЗНИКИ МОЛОКА
}

\section{Н. С. Щербакова, Ю. Ю. Максимова,}

Полтавська державна аграрна академія, м. Полтава, Україна

Однією з найнебезпечніших форм забруднення продуктів харчування та навколишнього середовищза є важкі метали, токсичні для людини і тварин. Ці речовини потрапляють в організм людини переважно через їжу. 3 иієї причини важливо визначити джерела накопичення та забруднення і простежсти иляхи цих металів до сільськогосподарської продукиії. Запобігання небезпечного впливу важких металів на здоров'я людини має трунтуватися на заходах, що охоплюють всю міграиійну ланку, від зменшення накопичення металів у природному середовищі до контролю їх вмісту у проду- 


\section{ВЕТЕРИНАРНА МЕДИЦИНА}

ктах харчування. Сільськогосподарські тварини є провідною ланкою в системі трунт-рослинатварина-їжа, яка отримує різні органічні речовини й хімічні елементи, зокрема важкі метали з кормом і водою. Молоко є найбільш «сприйнятливим» до важких металів. Найбільш токсичними елементами є свинецьь, ртуть, кадмій, цинк і мии'як. Дослідження проводили 2019 року на базі Регіональної державної лабораторії Держпродспоживслужби в Полтавській області. Всього було досліджено 12 проб молока коров'ячого незбираного - по одній пробі з партії. При проведенні дослідження на органолептичні показники звертали увагу на колір, смак, запах, консистенцію. Досліджуючи хімікоаналітичні властивості, молока визначали масову концентрацію мікро- та макроелементів за допомогою відповідних процедур випробувань та сучасних приладів. У результаті досліду хімікоаналітичних властивостей встановили, щзо вміст ртуті (Нd) у досліджуваних пробах відповідає нормі. Вміст кадмію (Cd) у пробі № 2 становить 0,056 мг/кг, у пробі № 3 - 0,042 мг/кг, у пробі № 9 0,047, а у пробі № 10 - 0,059 при гранично допустимому рівні 0,03 мг/кг, щуо на 86,6, 40, 56 та $96 \%$ більше норми відповідно. Показники по циннку (Zn) у досліджуваних пробах перебувають у межах норми. Вміст свинцю (Pb) у пробі № 2 становить 0,233 мг/кг, шуо на 133 \% більше за норму. Вміст свиницю (Pb) у пробі № 3 становить 0,285 мг/кг, щзо на $185 \%$ перевищує гранично допустимі рівні. У пробі № 9 вміст свинцю становить 0,249, а у пробі № 10 - 0,265, щзо на $149 \%$ і на $165 \%$ відповідно більше за норму. Концентрачія миш'яку (As) у досліджуваних пробах перебувають у межах норми. За органолептичними показниками всі досліджувані проби відповідали держвимогам ДСТУ 3662:2018 «Молоко-сировина коров'яче. Технічні умови».

Ключові слова: важкі метали, токсичні елементи, органолептичні показники, забруднення молока, хіміко-аналітичні дослідження.

\section{ВЛИЯНИЕ ТОКСИЧЕСКИХ ЕЛЕМЕНТОВ НА ОРГАНОЛЕПТИЧЕСКИЕ ПОКАЗАТЕЛИ МОЛОКА}

Н. С. Щербакова Ю. Ю. Максимова,

Полтавская государственная аграрная академия, г. Полтава, Украина

Одной из самых опасных форм загрязнения продуктов питания и окружающей среды являются тяжелье металлы, которые токсичны для человека и животных. Молоко является наиболее "восприимчивым" к тяжелым металлам. Самыми токсичными элементами являются свинец, ртуть, кадмий, цинк и мышьяк. Исследование проводили в 2019 на базе Региональной государственной лаборатории Госпродпотребслужбы в Полтавской области. Всего было исследовано 12 проб молока коровьего цельного - по одной пробе из партии. При проведении исследования на органолептические показатели обращули внимание на ивет, вкус, запах, консистенцию. При проведении химикоаналитических исследований молока определяли массовую концентрацию микро- и макроэлементов с помощью соответствующих процедур испьтаний и современных приборов. При проведении химикоаналитических исследований установили, что содержание ртути (Hd), ичика (Zn) и мышьяка (As) в исследуемых пробах соответствует норме. Содержание кадмия (Cd) в пробе № 2, № 3, № 9 и № 10 на 86,6\%, на 40\%, на $56 \%$ и на $96 \%$ больше нормы соответственно. Содержание свинца (Рb) в пробе № 2 на 133 \% больше нормы. Содержание свинца (Рb) в пробе № 3 на 185 \% превышает предельно допустимые уровни. В пробе № 9 и № 10 содержание свинца на $149 \%$ и на $165 \%$ соответственно больше нормы. По органолептическим показателям все исследуемые пробы соответствовали требованиям ДСТУ 3662:2018 «Молоко-сырье коровье. Технические условия».

Ключевые слова: тяжелье металлы, токсические элементы, органолептические показатели, загрязнение молока, химико-аналитические исследования

\section{Вступ}

Незбиране коров'яче молоко й молочні продукти з нього є важливим складовою частиною раціону людини. Тому вміст шкідливих речовин у молочних продуктах, що перевищує гранично допустимий рівень, може становити небезпеку для здоров'я населення. Однією з найнебезпечніших форм забруднення продуктів харчування та навколишнього середовища є важкі метали, які токсичні для людини i тварин. Ці речовини надходять в організм людини переважно через їжу. 3 цієї причини важливо визначити джерела накопичення та забруднення і простежити шляхи цих металів до сільськогосподарської продукції [1-5]. Запобігання небезпечного впливу важких металів на здоров’я людини має гру- 


\section{ВЕТЕРИНАРНА МЕДИЦИНА}

нтуватися на заходах, що охоплюють всю міграційну ланку, від зменшення накопичення металів у природному середовищі до контролю їх вмісту у продуктах харчування [6-8]. Сільськогосподарські тварини є провідною ланкою в системі грунт-рослина-тварина-їжа, яка отримує різні органічні речовини й хімічні елементи, зокрема важкі метали з кормом і водою.

У внутрішніх органах і продукції тварин, що утримуються в промислово розвинених регіонах, вміст важких металів, зокрема кадмію і свинцю, в кілька разів перевищує їх рівень у тварин 3 екологічно чистих зон [9-12]. Дослідники багатьох країн виявили, що кількість токсичних речовин, які потрапляють в організм тварин і надходять до продуктів тваринного походження, варіюється в широких межах. Цей рівень залежить від інтенсивності техногенного навантаження на сільськогосподарські угіддя, повноцінного раціону та умов утримання тварин. Основним джерелом токсичних речовин, зокрема важких металів, вважаються корми і питна вода [13-16].

Потрапляючи у продукти тваринного походження, шкідливі речовини можуть спричинити захворювання в людини і сприяти розвитку канцерогенних і мутагенних ефектів на організм. Молоко $є$ найбільш «сприйнятливим» до важких металів [17]. Найбільш токсичними елементами є свинець, ртуть, кадмій, цинк і миш’як. Джерелами їхнього надходження є відходи промислових підприємств, вихлопні гази автомобілів, мінеральні добрива та інше. Вони потрапляють в організм через дихальні шляхи, через питну воду або через їжу. Біологічні системи великої рогатої худоби нейтралізують токсичні речовини і лише невелика їх кількість потрапляє до молока. Однак вміст важких металів у молоці може збільшитися шляхом міграції їх з технологічних установок, полімерної та металевої тари, посуду та побутової техніки [18].

Фізичні властивості та якість молока як біологічного продукту є досить лабільними. Навіть незначні зміни в раціоні, навколишньому середовищі, умовах утримання й фізіологічному стані тварин приводять до деяких змін у молоці. До факторів, які спричиняють так звані пороки молока, відносять: фізіологічні зміни стану лактуючих тварин, хвороби тварин, недотримання умов утримання й годівлі, незадовільний стан тваринницьких приміщень, поганий стан пасовищ, введення в організм лікарських речовин, порушення первинної обробки молока та ін. Основні пороки пов'язані з кольором, запахом, консистенцією та смаком. Однак, як показали результати проведених досліджень, молоко, яке за органолептичними показниками відповідало державним вимогам, не відповідало Держстандарту за показниками безпеки. Для повної оцінки якості молока, крім органолептичних і фізико-хімічних показників, його треба досліджувати на вміст токсичних мікро- та мікроелементів.

Тому метою роботи було визначити вплив токсичних елементів на органолептичні показники молока. Задля досягнення поставленої мети необхідно було розв’язати наступні завдання: дослідити вміст токсичних мікро- та макроелементів у молоці коров'ячому незбираному.

Матеріали і методи досліджень

Дослідження проводили 2019 року на базі Регіональної державної лабораторії Держпродспоживслужби в Полтавській області, яка знаходиться за адресою Полтавська область, Полтавський район, село Горбанівка, вул. Миру 2.

Матеріалом досліджень було молоко коров’яче незбиране. Всього було досліджено 12 проб - по одній пробі з партії. Молоко надходить на дослідження у пластиковій тарі з надписом, що містить порядковий номер проби і вид дослідження, яке необхідно провести. До кожної проби додається супровідна.

Органолептичну оцінку молока проводили для визначення його якості й віднесення до певного сорту відповідно до вимог ДСТУ 3662:2018 [19].

При цьому встановлювали колір, запах, смак і консистенцію молока.

Визначення вмісту токсичних елементів здійснювали методом атомно-абсорбційної спектрометрії 3 атомізацією в полум’і, методом прямого аналізу, колориметричним методом та методом атомноемісійної спектрометрії з індуктивно-зв’язаною плазмою [20-23].

Визначення важких металів методом атомно-абсорбційної спектрометрії полягає у використанні атомізації в повітряно-ацетиленовому полум’і, 3 нагріванням пальника до температури близько $3000{ }^{\circ} \mathrm{C}$. Реєструється величина резонансного поглинання випромінювання на аналітичній довжині хвилі, що відповідає досліджуваному металу. Масову частку металу в мінералізаті зразка розраховують за градуювальною залежністю величини поглинання від масової концентрації металу [20].

Оцінка якості молока методом прямого аналізу базується на принципі прямого аналізу ртуті (без проведення підготовки проб) шляхом термічного розкладання проби та концентрації парів ртуті на золотому ама- 


\section{ВЕТЕРИНАРНА МЕДИЦИНА}

льгаматорі, десорбції ії та кількісному визначенні за допомогою атомно-абсорбційного аналізу [21].

Визначення концентрації миш'яку в молоці колориметричним методом базується на інтенсивності забарвлення розчину комплексного з'єднання миш'яку з діетилдітіокарбоматом срібла у хлороформі [22].

Метод атомно-емісійної спектрометрії з індуктивно-зв'язаною плазмою заснований на використанні для збудження характеристичного спектру нагрівання дрібнодисперсного аерозолю речовини, що аналізується в аргоновій плазмі високочастотного розряду та реєстрації оптичного спектру випромінення збуджених атомів. Варто зазначити, що цей метод $є$ більш чутливим і здатний виміряти нижчі концентрації токсичних елементів порівняно з атомно-абсорбційним методом [23].

\section{Результати досліджень та їх обговорення}

При проведенні дослідження на органолептичні показники звертали увагу на колір, смак, запах, консистенцію. За органолептичними показниками проби відповідали ДСТУ 3662:2018 «Молокосировина коров'яче. Технічні умови» [19]. Всі проби мали білий або дещо жовтуватий колір, приємний специфічний запах, солодкуватий смак та однорідну без осаду консистенцію.

Проводячи хіміко-аналітичні дослідження, виявили, що вміст ртуті (Нd) у досліджуваних пробах відповідає нормі. Вміст кадмію (Cd) у пробі № 2 становить 0,056 мг/кг, в пробі № $3-0,042$ мг/кг, в пробі № 9 - 0,047, а в пробі № 10 - 0,059 при гранично допустимому рівні 0,03 мг/кг, що на 86,6 \%, на $40 \%$, на $56 \%$ і на $96 \%$ більше норми відповідно (рис. 1).

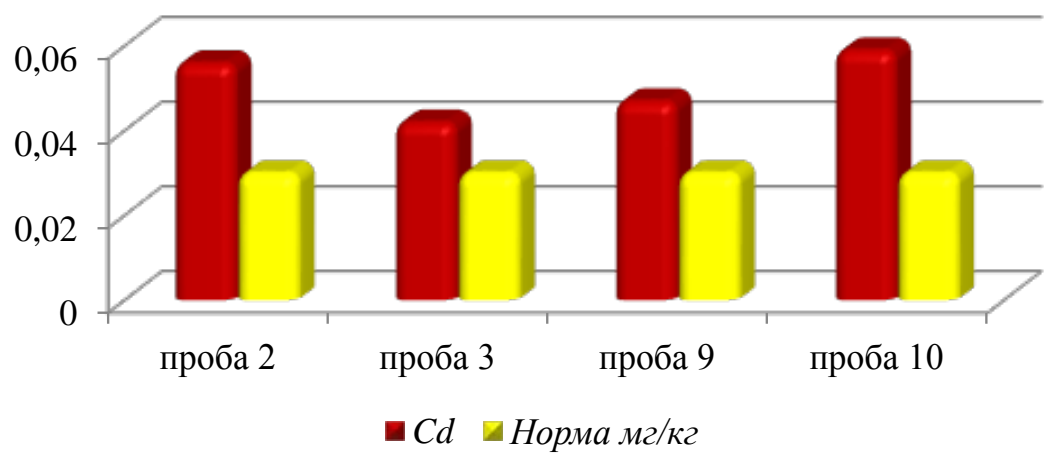

Рис. 1. Позитивні результати по кадмію

Показники по цинку (Zn) у досліджуваних пробах перебувають у межах норми. Вміст свинцю (Pb) у пробі № 2 становить 0,233 мг/кг, що на 133 \% більше за норму. Вміст свинцю (Pb) у пробі № 3 становить 0,285 мг/кг, що на 185 \% перевищує гранично допустимі рівні. У пробі № 9 вміст свинцю становить 0,249 , а в пробі № $10-0,265$, що на $149 \%$ і на $165 \%$ відповідно більше за норму (рис. 2). Концентрація миш'яку (As) у досліджуваних пробах є в межах норми.

Отже, при проведенні аналізу результатів досліджень молока, встановили, що молоко другої, третьої, дев'ятої і десятої проби не відповідає ДСТУ 3662:2018 «Молоко-сировина коров'яче. Технічні умови» [19]. Молоко, яке не відповідає державним вимогам, вважається небезпечним для харчування людей і молодняка с/г тварин. Особливо небезпечним для організму людей і тварин $\epsilon$ кадмій. Він міститься в мазуті й дизельному паливі (і звільняється при його спалюванні). Тому корма рослинного походження, які були заготовлені з пасовищ поблизу автомагістралей вважаються найбільш небезпечним джерелом важких металів. За даними досліджень багатьох учених відомо, що серед важких металів найбільше з кормів у молоко трансформується кадмій [7]. Найбільше кадмію накопичується в листках та коренях рослин, а також у зерні (особливо в насінні соняшника). Це свідчить про те, що однією з причин збільшення концентрації кадмію в молоці досліджуваних проб є недоброякісні корми рослинного походження зі збільшеним вмістом цього елемента.

Потрібно зазначити, що вміст важких металів у зелених кормах не повинен перевищувати максимально допустимого рівня. Для кадмію 0,3 мг/кг (при 12 \% вологості корму); для свинцю (при 12 \% вологості корму) 30 мг/кг відповідно до державних норм [24]. При збільшеному вмісті цих елементів може виникнути токсикоз, за якого у тварин переважно уражуються нирки, кровотворні органи (анемія), нервова й серцевосудинна системи, пригнічується активність багатьох ферментів, порушується обмін речовин і біосинтез. 


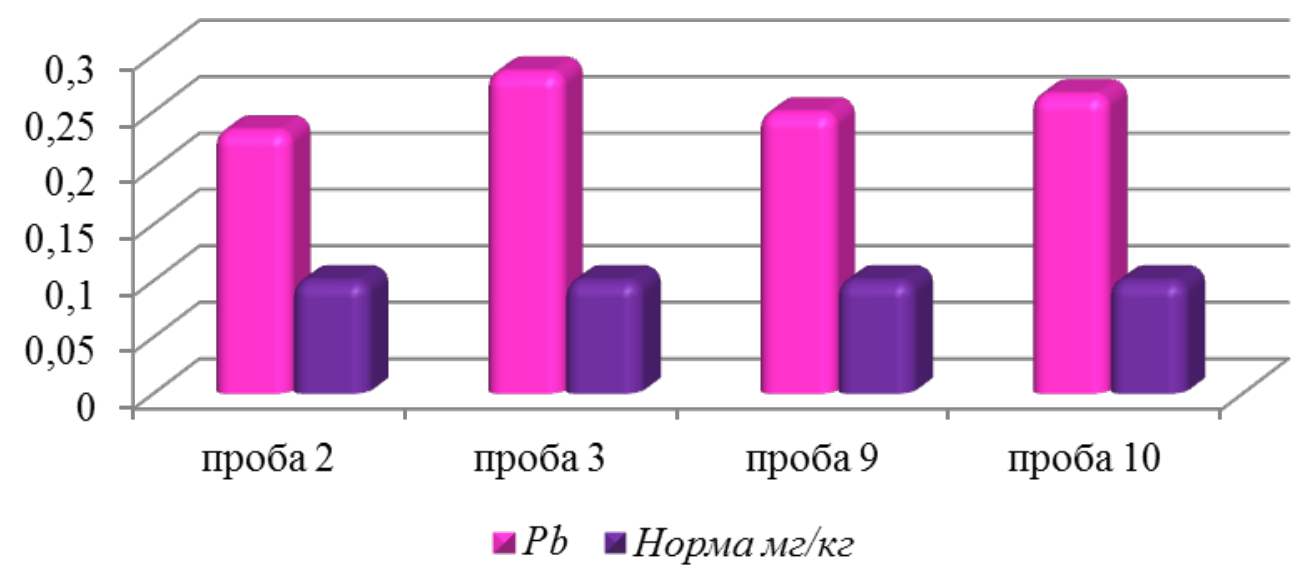

Рис. 2. Позитивні результати по свинцю

Як свідчать дані літератури $[1,3,10,11]$, в екологічно забруднених регіонах внаслідок впливу різних токсикантів, зокрема важких металів, відбувається порушення обміну речовин та імунобіологічної реактивності організму сільськогосподарських тварин. Екологічно забруднені молочні та м'ясні продукти негативно впливають на здоров'я людини $[12,26]$. Якщо шкідливі речовини потрапляють до продуктів тваринного походження, то вони можуть стати причиною захворювань у людини, сприяти виникненню канцерогенного й мутагенного ефектів на організм.

\section{Висновки}

Масова концентрація кадмію і свинцю в досліджуваних пробах не відповідає гранично допустимим рівням. Тому проаналізувавши результати досліджень, дані літератури та державні вимоги, робимо висновок про те, що проби з показниками, які перевищують норму, вважаються небезпечними й не допускаються до реалізації. Першоджерелом підвищеного вмісту кадмію і свинцю є корми рослинного походження. Незбиране коров'яче молоко та молочні продукти найбільш «сприйнятливі» до важких металів. Токсичний вплив важких металів в організмі реалізується повільно. Він проявляється зниженням функції окремих органів і систем, імунодефіцитним станом організму, а також може спричинити мутагенну, тератогенну й ембріотоксичну дію на організм продуктивних тварин і молодняку.

Перспективи подальших досліджень. Детально вивчити шляхи міграції важких металів у навколишньому середовищі та попередити їх потрапляння до продукції тваринного походження.

\section{References}

1. Bogatyrev, A. N. (2003). O proizvodstve jekologicheski bezopasnoj pishhevoj produkcii. Molochnaja Promyshlennost, 2, 17-19 [In Russian].

2. Zasekin, D. A. (2000). Detoksykatsiia nadlyshku vazhkykh metaliv v orhanizmi tvaryn - zaporuka zberezhennia zdorov'ia ta oderzhannia ekolohichno chystoi tvarynnytskoi produktsii. Naukovyi Visnyk Natsionalnoho Ahrarnoho Universytetu, 28, 258-269 [In Ukrainian].

3. Zasekin, D. A., Shabelnik, M. M., \& Melnychuk, D. A. (1995). Zabrudnenist hruntiv ta vody vazhkymy metalamy - odna z prychyn vynyknennia patolohii obminu rechovyn u tvaryn. Materialy naukovopraktychnoi konferentsii „Neinfektsiina patolohiia tvaryn”. Bila Tserkva: LitVudan [In Ukrainian].

4. Sager, M., Pechhacker, H., \& Pechhaker, M. (2001). Trace elements in honey. Federal office and Research Contre of Agriculture. New York: CRS Press.

5. Kalashnikov, V. I., Kuznyecov, S. G. \& Omelchenko, V. D. (2000). Mineralnyj obmen v organizme molochnyh korov pri razlichnyh usloviyah pitaniya. Sovremennye problemy biotehnologii i biologii produktivnyh zhivotnyh. Sb.nauch.trudov. Borovsk [In Russian].

6. Kravtsiv, R. Y. (2002). Vprovadzhennia novykh ekolohichno bezpechnykh tekhnolohii u vyrobnytstvo - odyn z priorytetnykh napriamkiv rozvytku narodnoho hospodarstva Ukrainy. Naukovyi Visnyk Lvivskoi Derzhavnoi Akademii Veterynarnoi Medytsyny im. S.Z. Hzhytskoho, 2, 6-13 [In Ukrainian].

7. Pylypiv, I. I. (2005). Biokhimichni pokaznyky moloka i krovi koriv ta yikh arterio-venozna riznytsia u molochnii zalozi pry eksperymentalnomu navantazhenni kadmiiem. Naukovo - Tekhnichnyi Biuleten 


\section{ВЕТЕРИНАРНА МЕДИЦИНА}

Instytutu Biolohii Tvaryn i Derzhavnoho Naukovo-Doslidnoho Kontrolnoho Instytutu Vetpreparativ ta Kormovykh Dobavok, VI (1), 134-138 [In Ukrainian].

8. Babiuk, A. V., Makarova, O. V., Rohozynskyi, M. S., \& Romaniv, L. V. (2005). Bezpeka kharchuvannia: suchasni problemy: posibnyk-dovidnyk. Chernivtsi: Knyhy - XXI [In Ukrainian].

9. Butsiak, V. I., \& Pechar, N. P. (2007). Biotekhnolohichni aspekty vyrobnytstva ta pererobky moloka za umov tekhnohennoho navantazhennia. Naukovyi Visnyk Lvivskoi Derzhavnoi Akademii Veterynarnoi Medytsyny im. S.Z. Hzhytskoho, 2 ((33) 2), 7-12 [In Ukrainian].

10. Pylypiv, I. I., \& Fedoruk, R. S. (2000). Dzherela zabrudnennia dovkillia okremymy vazhkymy metalamy ta yikh vplyv na zhyttiediialnist orhanizmu tvaryn. Naukovo-Tekhnichnyi Biuleten Instytutu Biolohii Tvaryn, II, 26-32 [In Ukrainian].

11. Ashton, J. F., \& Laura, R. S. (1992). The cadmium problem. Search, 23 (1), 31-33.

12. Stopper, M. (1991). Cadmium. Metals and their Cowponnds Environ: Octurence, Analysis and Biol. Weinheim: Relevance.

13. Gaetke, L. (2003). Copper toxicity, oxidative stress, and antioxidant nutrients. Toxicology, 189 (1-2), 147-163. doi: 10.1016/s0300-483x(03)00159-8.

14. Gooneratne, S. R., \& Christensen, D. A. (1997). Effect of chelating agents on the excretion of copper, zinc and iron in the bile and urine of sheep. The Veterinary Journal, 153 (2), 171-178. doi: 10.1016/s10900233(97)80037-8.

15. Barabanshikov, N. V.(1980). Kachestvo moloka i molochnyh produktov. Moskva: Kolos [In Russian].

16. Kartashova, V. M. (1980). Gigiena poluchenija moloka. Moskva: Kolos [In Russian].

17. Suttle, N. F. (1991). The Interactions Between Copper, Molybdenum, and Sulphur in Ruminant Nutrition. Annual Review of Nutrition, 11 (1), 121-140. doi: 10.1146/annurev.nu.11.070191.001005.

18. Müller, M., \& Anke, M. (1994). Distribution of cadmium in the food chain (soil-plant-human) of a cadmium exposed area and the health risks of the general population. Science of The Total Environment, 156 (2), 151-158. doi: 10.1016/0048-9697(94)90352-2.

19. DSTU ISO 3662:2018. Moloko-syrovyna korov'iache. Tekhnichni umovy. Chynnyi vid 2019-01-01. (2019). Kyiv [In Ukrainian].

20. Protsedura vyprobuvan № 44. (2017). Vyznachennia toksychnykh elementiv midi, tsynku, svyntsiu, kadmiiu ta zaliza $v$ kharchovykh produktakh ta kormakh metodom atomno-absorbtsiinoi spektrometrii z atomizatsiieiu u polumi, 41 [In Ukrainian].

21. Protsedura vyprobuvan № 62. (2017). Vyznachennia masovoi kontsentratsii za-halnoi rtuti $v$ kharchovykh produktakh, kormakh, kormovii ta prodovolchii syrovyni, vodi metodom priamoho analizu (termichne rozkladannia proby z podalshym atomno-absorbtsiinym analizom), 56 [In Ukrainian].

22. Protsedura vyprobuvan № 48. (2016). Vyznachennia mysh'iaku kolorymetrychnym metodom, 48 [In Ukrainian].

23. Protsedura vyprobuvan № 69. (2016). Vyznachennia mikro- ta makroelementiv v syrovyni, produktsii tvarynnoho ta roslynnoho pokhodzhennia, kormakh ta vodi metodom atomno-absorbtsiinoi spektrometrii z induktyvno-zv'iazanoiu plazmoiu, 63 [In Ukrainian].

24. Pro zatverdzhennia pereliku maksymalno dopustymykh rivniv nebazhanykh rechovyn u kormakh ta kormovii syrovyni dlia tvaryn: Zakon Ukrainy vid 5.04.2012 № 503/20816. (2012). Ministerstvo Yustytsii Ukrainy, 131. [In Ukrainian].

25. Van Bruwaene, R., Kirchmann, R., \& Impens, R. (1984). Cadmium contamination in agriculture and zootechnology. Experientia, 40 (1), 43-52. doi: 10.1007/bf01959101.

26. Trahtenberg, I. M., Kolesnikov, S. V., \& Lukovenko, V. P. (1994). Tjazhelye metally vo vneshnej srede. Sovremennye gigienicheskie i toksikologicheskie aspekty. Minsk: Nauka i tehnika [In Russian].

27. Gabovich, R. D., \& Priputina, L. S. (1987). Gigienicheskie osnovy ohrany produktov pitaniya ot vrednyh himicheskih veshestv. Kiev: Zdorov'ya [In Russian].

Стаття надійшла до редакції 10.11.2019 р.

Бібліографічний опис для цитування:

Щербакова Н. С., Максимова Ю. Ю. Вплив токсичних елементів на органолептичні показники молока. Вісник ПДАА. 2019. № 4. С. 153-158.

() Щербакова Наталія Сергї̈вна, Максимова Юлія Юріївна, 2019 